\title{
UTILIZATION OF SOYMILK AS MILK REPLACER FOR CALVES
}

\author{
A. K. M. Masum, M. N. Islam and M. A. S. Khan ${ }^{1}$
}

\begin{abstract}
An experiment was conducted to study the utilization of soymilk as milk replacer for raising calves. Nine crossbred calves were selected and divided into three groups on the basis of their body weight and genotype. The calves of group A were reared by cow milk, group $B$ reared by strained soymilk and group $C$ reared by unstrained soymilk. It was found that, total body weight gain of group A, B and C were $13.933 \pm$ $1.222,13.800 \pm 0.917$ and $13.233 \pm 1.537 \mathrm{Kg}$, respectively. There was no significant difference among the three groups of calves. Non-significant differences were also seen for increment in wither height $(5.588 \pm 0.508,5.419 \pm 0.529$ and $5.080 \pm 0.440 \mathrm{~cm}$, respectively), length $(6.096 \pm 0.440,5.927 \pm 0.388$ and $5.503 \pm$ $0.388 \mathrm{~cm}$, respectively) and heart-girth $(5.842 \pm 0.440,5.588 \pm 0.916$ and $5.419 \pm$ $0.388 \mathrm{~cm}$, respectively) of calves. Economic analysis showed that soymilk was cheaper than cow milk (Tk. 8.0 vs Tk. 44.0). It can be concluded that soymilk as milk replacer could be used successfully for raising dairy calves.
\end{abstract}

Key words: Soymilk, Cow milk, Calves, Body weight

\section{Introduction}

Calves contribute in establishing a future herd by replacing culled cows and bulls. The calf feeding programme is a most critical factor in the management of young calves. Although the milk production of our native cows are low but due to acute shortage of animal feeds they even cannot show their full genetical potentiality what they have. As a result, calves can not get required amount of milk. Raising young calves is one of the most often neglected jobs on the dairy farm. The future of herd's milk production begins before the calves are born. The first three or four months of calf's life is a critical period and the feeding programme at this time is important for rapid growth and development of baby calves and reducing death losses. Feeding of whole milk to calves is very expensive in a country like ours where demand of milk for human consumption is very high. Under these circumstances, we have to pay great attention on economic calf feeding programme. In a calf feeding programme, milk replacer and calf starter have been developed in many countries to reduce the amount of whole milk used in calf raising (Plaza and Fernandez, 1994; Sajko et al., 1998 and Mete et al., 2000). In some countries, soymilk is being used as a novel milk replacer in calf raising facilities (Ghorbani et al., 2007). Soymilk is a diet having a composition very close that of cow's milk, which is concerned with feeding the calf from the time it is taken from its mother, or

Department of Dairy Science, Bangladesh Agricultural University, Mymensingh-2202, Bangladesh

(Received: October 29, 2009) 
ceases to be fed colostrum. No research work has yet been done to develop soymilk as milk replacer in our country. Hence, research work in this area is urgently needed. This is why this work was undertaken for raising dairy calves economically by using soymilk.

\section{Materials and Methods}

This experiment was conducted with crossbred dairy calves at Bangladesh Agricultural University Dairy Farm for a period of eight weeks. Nine crossbred dairy calves of nearly similar in body weight ( 37.7 to $39.7 \mathrm{~kg}$ ) and age (about 1.5 to 2 months of age) were selected and divided into three groups (group A, B and C) considering their body weight and genotype in a Completely Randomized Design (CRD). The calves of group A were reared by feeding cow milk, group B reared by soymilk after straining and group $C$ reared by soymilk without straining.

Soymilk was prepared from the large size, thin hull and not more than 1 year old whole soybean. One $\mathrm{kg}$ whole soybean was grinded in a soy flour mill and $125 \mathrm{~g}$ powder was dissolved with $1000 \mathrm{ml}$ of water and strained with fine muslin cloth. Thereafter, soymilk was boiled at $100^{\circ} \mathrm{C}$ for 15 minutes with constant stirring. After proper cooling soymilk was supplied to the calves of group B. On the other hand, another batch of soymilk was prepared in the same way and offered to the calves of group $C$ without straining and calves of group A were supplied cow's milk collected from the Bangladesh Agricultural University Dairy Farm.

Whole milk and soymilk were given two times daily, once in the morning and again in the afternoon. Group A was continued with cow milk feeding system (1 litre cow milk for each calf), which was treated as control group and another two groups (group B and group C) were fed strained and unstrained soymilk, respectively at the same rate up to eight weeks study period. Green grasses were also supplied in the morning and afternoon at free choice throughout the experiment and $0.5 \mathrm{~kg}$ concentrate mixture was given only in the morning (wheat bran: rice polish: til oil cake: common salt= 6:3:1:0.3). The calves were weighed and their height, length, and heart girth were measured initially at starting of the experiment and subsequently once a week in the morning before offering their feed.

Milk samples were analyzed were the specific gravity, dry matter, fat, protein, ash and solids-not-fat (SNF) content by using the procedure described by Aggarwala and Sharma (1961). Green grass and concentrate mixture were analyzed to determine the proximate composition following the methods as described in AOAC (2003). The data were analyzed statistically by using MSTAT computer program (Steel and Torrie, 1980). Chemical composition and cost (Tk) of cow's milk and soymilk are shown in Table 1 and proximate composition of feed ingredients is shown in Table 2. 
Table 1. Chemical composition and cost (Tk.) of cow's milk and soymilk (on the fresh matter basis)

\begin{tabular}{|lcc|}
\hline \multicolumn{1}{|c|}{ Parameters } & Cow's milk & Soymilk \\
\hline Fat $(\mathrm{g} / \mathrm{kg})$ & 48.0 & 28.0 \\
Protein (g/kg) & 31.0 & 39.0 \\
Lactose/Carbohydrate $(\mathrm{g} / \mathrm{kg})$ & 45.0 & 36.0 \\
Ash (g/kg) & 7.0 & 6.5 \\
Total solids (g/kg) & 131.0 & 109.5 \\
Solids-not-fat (SNF, g/kg) & 83.0 & 81.5 \\
Water (g/kg) & 869.0 & 890.5 \\
Acidity (\%) & 0.155 & 0.145 \\
Specific gravity & 1.027 & 1.023 \\
Cost & Tk. 8.0/kg & Tk. 44.0/kg \\
\hline
\end{tabular}

Table 2. Proximate composition of other feed ingredients

\begin{tabular}{|l|c|c|c|c|c|c|}
\hline \multirow{1}{*}{ Ingredients } & DM & CP & CF & Ash & EE & NFE \\
\cline { 2 - 7 } & g/kg fresh & \multicolumn{5}{c|}{ g/kg DM } \\
\hline Wheat bran & 899.2 & 156.6 & 57.5 & 42.3 & 46.2 & 697.4 \\
Rice polish & 912.5 & 131.3 & 51.1 & 73.7 & 108.2 & 635.7 \\
Til oil cake & 914.0 & 269.4 & 206.3 & 148.0 & 99.9 & 276.64 \\
Common salt & 960.00 & - & - & - & - & - \\
\hline German grass & 215.2 & 85.9 & 317.3 & 130.1 & 28.2 & 438.5 \\
Para grass & 266.5 & 82.4 & 319.5 & 110.9 & 28.1 & 459.1 \\
\hline
\end{tabular}

\section{Results and Discussion}

The results of the changes in body weight, wither height, body length and hear girth of calves during the experimental period are shown in Table 3.

\section{Body weight (Kg)}

The average total body weight gain of the control (group A) and soymilk groups (group B and group C) were $13.933 \pm 1.222,13.800 \pm 0.917$ and $13.233 \pm 1.537 \mathrm{Kg}$, respectively. Daily weight gain were $0.249 \pm 0.022,0.246 \pm 0.016$ and $0.236 \pm 0.027 \mathrm{Kg}$ for control (group A) and soymilk groups (group B and group C), respectively (Table 3). There were no significant differences in total and daily weight gain among the three groups of calves. The result of the present study agrees with the findings of Wadud and Rahman (1978) and Rahman et al. (1988) who found that weight gain of whole milk feeding group was little higher than that of different milk replacer groups but the weight gain was not significant $(P>0.05)$. 
Bang. J. Anim. Sci. 2009, 38(1\&2)

Table 3. The changes in body weight, wither height, body length and hear girth of calves during the experimental period

\begin{tabular}{|c|c|c|c|c|}
\hline \multirow[t]{2}{*}{ Parameters } & \multicolumn{3}{|c|}{ Treatment groups $^{\#}$} & \multirow{2}{*}{ Level of sig. } \\
\hline & A & B & C & \\
\hline \multicolumn{5}{|c|}{ Body weight (kg) } \\
\hline Initial & $39.667 \pm 0.577$ & $37.667 \pm 1.528$ & $38.667 \pm 0.577$ & NS \\
\hline Final & $53.600 \pm 1.778$ & $51.467 \pm 1.665$ & $51.900 \pm 1.852$ & NS \\
\hline Total change & $13.933 \pm 1.222$ & $13.800 \pm 0.917$ & $13.233 \pm 1.537$ & NS \\
\hline Daily change & $0.249 \pm 0.022$ & $0.246 \pm 0.016$ & $0.236 \pm 0.027$ & NS \\
\hline \multicolumn{5}{|c|}{ Wither height (cm) } \\
\hline Initial & $72.221 \pm 1.531$ & $70.467 \pm 1.361$ & $71.503 \pm 1.463$ & NS \\
\hline Final & $77.829 \pm 1.054$ & $75.856 \pm 1.829$ & $76.587 \pm 1.397$ & NS \\
\hline Total change & $5.588 \pm 0.508$ & $5.419 \pm 0.529$ & $5.080 \pm 0.440$ & NS \\
\hline Daily change & $0.100 \pm 0.009$ & $0.097 \pm 0.009$ & $0.091 \pm 0.008$ & NS \\
\hline \multicolumn{5}{|l|}{ Body length (cm) } \\
\hline Initial & $59.013 \pm 1.444$ & $59.944 \pm 2.423$ & $57.635 \pm 1.761$ & NS \\
\hline Final & $65.126 \pm 1.892$ & $65.871 \pm 2.798$ & $63.123 \pm 1.761$ & NS \\
\hline Total change & $6.096 \pm 0.440$ & $5.927 \pm 0.388$ & $5.503 \pm 0.388$ & NS \\
\hline Daily change & $0.109 \pm 0.008$ & $0.106 \pm 0.007$ & $0.098 \pm 0.007$ & NS \\
\hline \multicolumn{5}{|l|}{ Hear girth $(\mathrm{cm})$} \\
\hline Initial & $82.635 \pm 1.552$ & $79.756 \pm 1.586$ & $81.873 \pm 1.691$ & NS \\
\hline Final & $88.477 \pm 1.973$ & $85.373 \pm 1.453$ & $87.269 \pm 1.455$ & NS \\
\hline Total change & $5.842 \pm 0.440$ & $5.588 \pm 0.916$ & $5.419 \pm 0.388$ & NS \\
\hline Daily change & $0.105 \pm 0.008$ & $0.100 \pm 0.017$ & $0.097 \pm 0.007$ & NS \\
\hline
\end{tabular}

$\mathrm{A}=$ Feeding cow milk, $\mathrm{B}=$ Feeding soymilk after straining, $\mathrm{C}=$ Feeding soymilk without straining NS = Non-significant

\section{Wither height (cm)}

Total height changes from initial to week 8 were $5.588 \pm 0.508,5.419 \pm 0.529$ and 5.080 $\pm 0.440 \mathrm{~cm}$ for group A, group B and group C, respectively. On the other hand, daily height changes were $0.100 \pm 0.009,0.097 \pm 0.009$ and $0.091 \pm 0.008 \mathrm{~cm}$ for control (group A) and soymilk groups (group B and group C), respectively (Table 3). Statistically no significant differences were seen for total and daily height gain of three groups of calves. Similar results were also reported by Rahman et al. (1988) and Mete et al. (2000) who did not find any changes in wither height.

\section{Body length (cm)}

The average total increase of length were $6.096 \pm 0.440,5.927 \pm 0.388$ and $5.503 \pm$ $0.388 \mathrm{~cm}$ for the calves of group A, group B and group C, respectively. Daily changes in length in the same order for three groups were $0.109 \pm 0.008,0.106 \pm 0.007$ and 0.098 $\pm 0.007 \mathrm{~cm}$, respectively (Table 3 ). Statistical analysis showed that no significant 
differences were seen for total and daily increment in length for all groups of calves. Wadud and Rahman (1978), Rahman et al. (1988) and Mete et al. (2000) also observed similar results among the groups of calves when calves were fed milk and milk replacer.

\section{Heart girth (cm)}

Total heart girth changes from initial to week 8 were $5.842 \pm 0.440,5.588 \pm 0.916$ and $5.419 \pm 0.388 \mathrm{~cm}$ for group A, group B and group C, respectively. On the other hand, daily heart-girth changes were $0.105 \pm 0.008,0.100 \pm 0.017$ and $0.097 \pm 0.007 \mathrm{~cm}$ for control (group A) and soymilk groups (group B and group C), respectively (Table 3). Statistically no significant differences were seen for total and daily changes in heart girth for all groups of calves. Similar performance was also found by Rahman et al. (1988) and Mete et al. (2000) who observed that gain in heart girth among the groups of calves were non-significant $(P>0.05)$.

The daily intake of liquid feed (milk and milk replacer) and concentrate mixture in all groups were nearly similar. On an average, it was found that calves of control and soymilk groups consumed about $0.5 \mathrm{Kg}$ concentrate mixture per head per day. On the other hand, green grass consumption was 4.2, 4.4 and $4.0 \mathrm{Kg}$ per head per day for control (group A) and soymilk groups (group B and group C), respectively. In all cases, statistical differences were non-significant. Cost of each $\mathrm{Kg}$ of soymilk was about eight taka (Tk. 8) but the same figure for $1 \mathrm{Kg}$ of cow milk was forty four taka (Tk. 44) (Table 1). Economic analysis showed that soymilk as a milk replacer was 5.5 times cheaper than whole milk feeding. Soymilk is not only cheaper but it has also nearly similar effect on body weight changes. The ingredients used for making this soymilk are easily available in the local markets and manufacturing process is also easy. Raising calves based on soymilk feeding will reduce the pressure on the fluid milk. As a result, availability of fluid milk in the local markets will be increased; at the same time, calves will get the required amount of nutrients from the soymilk. This will ultimately help to produce future replacement stock for a dairy farm. So, farmers of our country could easily use soymilk for rearing their calves which is already being practiced in the developed countries in the world.

\section{Conclusion}

From the results of the present experiment it may be recommend that soymilk as a milk replacer could be used successfully for raising the dairy calves.

\section{Acknowledgement}

The authors are acknowledged gratefully to the Bangladesh Agricultural University Research System (BAURES) for financial help. 
Bang. J. Anim. Sci. 2009, 38(1\&2)

\section{Literature Cited}

Aggarwala, A. C. and Sharma, R. M. 1961. A laboratory manual of milk Inspection. $4^{\text {th }}$ edition, Asia Publishing House, Bombay, Calcutta, New Delhi, India.

AOAC. 2003. Official Methods of Analysis (17 $7^{\text {th }} \mathrm{Ed}$.). Association of Official Analytical Chemists. Washington. DC, USA.

BBS (Bangladesh Bureau of Statistics). 2004. Statistical Year Book of Agriculture. Statistics Divisions, Ministry of Planning, Government of Bangladesh.

Ghorbani, G. R., Kowsar, R., Alikhani, M. and Nikkhah, A. 2007. Soymilk as a Novel Milk Replacer to stimulate early calf starter intake and reduce weaning age and costs. J. Dairy Sci. 90(12): 5692-5697.

Mete, Y., Sadrettin, Y., Ugur, Z., Yanar, M., Yuksel, S. and Zulkadir, U. 2000. Replacement of whole milk by milk replacer in the ration of Holstein-Friesian calves raised in Eastern Turkey. Indian j. Anim. Sci. 70(9): 977.

Plaza, J. and Fernandez, E. 1994. Effect of whole milk substitution by a milk replacer (MR) on calf performance. Cuban J. Agric. Sci. 28(1): 49.

Rahman, F., Rahman, M. S., Rahman, A., Wadud, A. and Husain, S. M. I. 1988. Study on the growth performance of baby calves as influenced by milk replacers. Bangladesh J. Agric. Sci. Vol. 15(1): 189.

Sajko, J., Skorko, S. H., Tywonczuk, J., Zuraw, J. and Chojnowski, W. 1998. Efficiency of milk replacer containing soycomil $\mathrm{K}$ in calf feeding. Acta. Acad. Agric. Tech. Olstenensis, Zootechnica, No. 48: 45.

Steel, G. D. and Torrie, J. H. 1980. Principles and Procedure of Statistics. McGraw Hill Book Company, New York.

Wadud, A. and Rahman, M. S. 1978. Performance of baby calves fed milk replacers comprising of locally available ingredients. Bangladesh Vet. J. Vol. 12(1-4): 16. 